\title{
Protected area management and local access to natural resources: a change analysis of the villages neighboring a world heritage site, the Keoladeo National Park, India
}

\author{
Mohd. Zeeshan ${ }^{1 *}$, B. Anjan Kumar Prusty ${ }^{2}$ and P. A. Azeez ${ }^{1}$
}

\begin{abstract}
A network of Protected Areas (PAs) has been the main strategy adopted in India for conservation of biodiversity and wildlife. Thus, more than 600 PAs are established; however, pressures from the human settlements in the proximity have been a serious concern for their management. To appreciate the interplay of governance of PAs and human settlements around them, we selected Keoladeo National Park (KNP), a Ramsar and world heritage site in India, as a model. We compared the socio-economic state of the inhabitants in the 13 villages and their dependency on KNP for resources two decades ago with that of the present. Information on socio-economic indicators was collected from the villagers using a customized questionnaire. Data was also collected from concerned government departments. Significant changes in human population, literacy, households, fuel use, water level, agriculture, occupations and irrigation techniques were seen. Much of the traditional agricultural fields are now open for other uses. The changes reflect reconciliation by the neighborhood community with the governance strategy and a shift in their resource utilization. The major local driver for the changes was an abrupt change in conservation praxis in the KNP.
\end{abstract}

Keywords: Conservation governance, Keoladeo National Park, Protected areas, Ramsar site, Socio-economics, World heritage site, Villages

\section{Introduction}

Protected areas (PAs - national parks, wildlife sanctuaries, and reserve forests) are planned and managed with the prime objective of biodiversity conservation (Bruner et al. 2001; Wilkie et al. 2008). The PAs, generally considered the core units for in-situ conservation, provide several ecosystem goods and services of direct and indirect use values, optional values, and the existence or nonuse values (Schreckenberg et al. 2016; Weisbrod, 1964; Krutilla, 1967; Arrow \& Fischer 1974). Across the world, the number of PAs has almost doubled in the past 2 decades (Deguignet et al., 2014), and the number (recorded

\footnotetext{
*Correspondence: malik908@gmail.com

${ }^{1}$ Sálim Ali Centre for Ornithology and Natural History (SACON), Anaikatty

(PO), Coimbatore 641108, Tamil Nadu, India

Full list of author information is available at the end of the article
}

in the World Data base on Protected Areas) lately is 202,467 terrestrial and inland water protected areas, covering $14.7 \%$ of the world's extent of these ecosystems (UNEP-WCMC and IUCN, 2016). Almost all PAs have human habitations abutting their boundaries, which intricately interact with wildlife and habitats within (Mulongoy \& Chape, 2004; Chape et al. 2005). Thus, PAs are under human pressure, from population growth and land use intensification, a major issue for the management (Cincotta et al. 2000). Effect of PAs on their human neighbors is a widely debated issue (Adams et al., 2004; Brockington et al. 2006; Joppa et al. 2009). The importance of managing such interplays, positive and negative, vital in sustaining the ecological setting of the PAs, is well recognized (DeFries et al. 2010; Pullin et al., 2013). The Convention on Biological Diversity (2010) 
has been consistently advocating involvement of indigenous people and stakeholders, and equitable and effective management of PAs. However, across the world and particularly in India not much progress is made in this line.

The Protected Area network in India is spread over the country covering $4.9 \%$ of its geographical area (102 national parks, 515 wildlife sanctuaries, 47 conservation reserves and four community reserves, Ministry of Environment \& Forests, 2013). Protected areas, especially national parks and sanctuaries, have been the model for conservation of biodiversity in India, adopting an administrative and management strategy that largely excludes the local or indigenous communities, even at locations where their traditional resources are well within the area possibly conflicting with the equity criteria in the context of biodiversity conservation. India has been remarked as ardently holding on to the philosophy of protection rather than conservation bridging the gap between people and managers (Jung, 2015). As this model accrues little direct and tangible benefits to the local communities, probably depriving them of the direct benefits, it fails in drawing their participation in conservation activities. Lately, the policy makers in India, in rhyme with the international trend, are increasingly recognizing this limitation and the need to involve locals through participatory conservation. That would help to an extent in reconciling the conservation conflicts, the conflict of passionate conservationists' demand for total protection and the demands from human livelihood and well-being (Redpath et al. 2015). The conflict in the case of Keoladeo National Park (KNP) was of seemingly incompatible goals, the goal of its management and that of the local inhabitants. The explicit conflicts concerning the local inhabitants are related to non-recognition of the traditional resource-use practices, and local aspirations for social welfare and better livelihood options. Therefore this PA, formerly a royal hunting ground, declared wildlife sanctuary in 1971, Ramsar site in 1981 (one of the two initial sites in India), National Park in 1982, and UNESCO World Heritage Site in 1985 (first natural site in India) was selected as a model. Until the late 1990s, KNP was the only wintering ground for the central population of Siberian cranes (Grus leucogeranus) in South Asia; unfortunately, since 2002, these birds stopped coming there. KNP, a mosaic of wetland, woodland, and grassland, is known to have 404 species of plants, 380 species of birds, 65 species of fish, 49 species of butterflies and 29 species of amphibians and reptiles (Prusty et al. 2013). The development of KNP to its present state has been eventful, reconciling several conflicts of interests (Azeez, 1992), of which the most striking were the conflicts relating to access to its resources mainly for grazing and that relating to water release. The KNP is critically dependent on the water flow from its catchment, which in recent years have grown into a matter of serious contention with the public. The demand in the upstream areas results in diversion of more water for agriculture and domestic uses. Consequently, during the past couple of decades, KNP has been facing serious shortage of water (Prusty et al. 2011).

During the mid- $18^{\text {th }}$ century, the area as a waterfowl and duck shooting reserve for the then rulers of Bharatpur and their regal guests, was also meeting two direct resource requirements of the local villages: i) fodder and grazing ground for livestock, and ii) fuel wood. Albeit the rulers of Bharatpur assigned the ownership of the area to the government in 1971, the rights of the locals for grazing livestock and collection of fodder and fuel wood was retained until 1982. The abrupt ban on grazing and collection of fuel wood, upon upgrading the area from a wildlife sanctuary (Bharatpur Bird Sanctuary) to a national park (KNP), where no human activity including removal of forest produce or grazing is allowed as per the Wildlife Protection Act - 1972, gave a severe jolt to the villagers mostly engaged in livestock rearing and agriculture, and evoked intense protests and distress. The immediate result was some clashes between the local community, farmers and the Government. Habituated to sourcing fuel wood, thatch grasses, and fodder free of cost for generations, the ban forced the villagers to procure these from markets at a price, a mechanism they were not extensively accustomed to earlier. Most of the villages, essentially agrarian, agriculture and livestock being their prime source of livelihood (Azeez et al. 1992), had intricate linkages of traditions, castes and Societal segments. The ban on the direct use of the KNP by the villagers was imposed under the then prevailing view on wetland ecosystem dynamics (Vijayan, 1991). It resulted in an immediate impact on the local economy in terms of direct usage of natural resources, occupations and income, and in subsequent years its ecology. The ban on direct usage of the natural resources and souring raw materials inevitable for their traditional livelihood from the park led to vehement protest from the locals. Its ecological setting visibly changed with formation of a thick mat of wetland grass mainly Paspalam distichum (Shukla, 1998) and other hydrophytes, enormous accumulation of detritus, invasion by terrestrial weeds and consequent decline in water birds coming to the park for wintering. The expansive growth of emergent macrophytes created a situation where open-water area with submerged hydrophytes essential for many the migratory waterfowl are evidently reduced.

Upon adopting the conservation strategy that was in vogue for long (Vijayan, 1991), currently KNP is under strict conservation-oriented management by the Rajasthan Forest department. Now it is open only for 
researchers and tourists under controlled access. Grazing and free entry of people are banned; however, the management employs some of the locals. In this context, three decades after the ban of entry to the KNP for direct use of the biological resources, we undertook a household level survey in its neighborhood. The aim of the study was to explore the current linkages and state of resource dependency between the neighboring human settlements and the PA Consequent to the ban. The National Park was selected as a model since it is a renowned conservation site existing for long amidst a bucolic and agricultural landscape, the first Ramsar site and first natural world heritage site in India, neighboring a fast growing urban center and district headquarters, and widely acknowledged tourist attraction.

\section{Study area}

The KNP is located at $27^{\circ} 7.6^{\prime}-27^{\circ} 12.2^{\prime} \mathrm{N}$ and $77^{\circ} 29.5^{\prime}$ $77^{\circ} 33.9^{\prime} \mathrm{E}, 2 \mathrm{~km}$ from Bharatpur town. It was a natural depression flooded by the rivers Banganga and Gambhiri (perennial rivers in the past, Additional file 1: Figure S1: Location of Gambhiri river, Panchana dam, KNP and Bharatpur city) until the construction of Ajan dam at their confluence by then local ruler Suraj Mal (Vijayan, 1991). Spread over $28.33 \mathrm{~km}^{2}$, it is the only National Park in India enclosed by a masonry boundary wall (1.82 m high, built during 1977-1981; Gujja, 1995). Croplands and villages surround the Park on all sides, except its northwestern side (previously an important roosting site for birds) where residential colonies have come up recently. The growing Bharatpur city has almost embraced all the nearby area and wilderness through expanding urban sprawls (Fig. 1), which has further shrunk the resource base for birds outside the KNP.

\section{Methods}

In each village, the household survey was conducted from January to June 2012 using a custom-made questionnaire (Table 1), rather an interview schedule, designed to elicit the details in a historical perspective (see

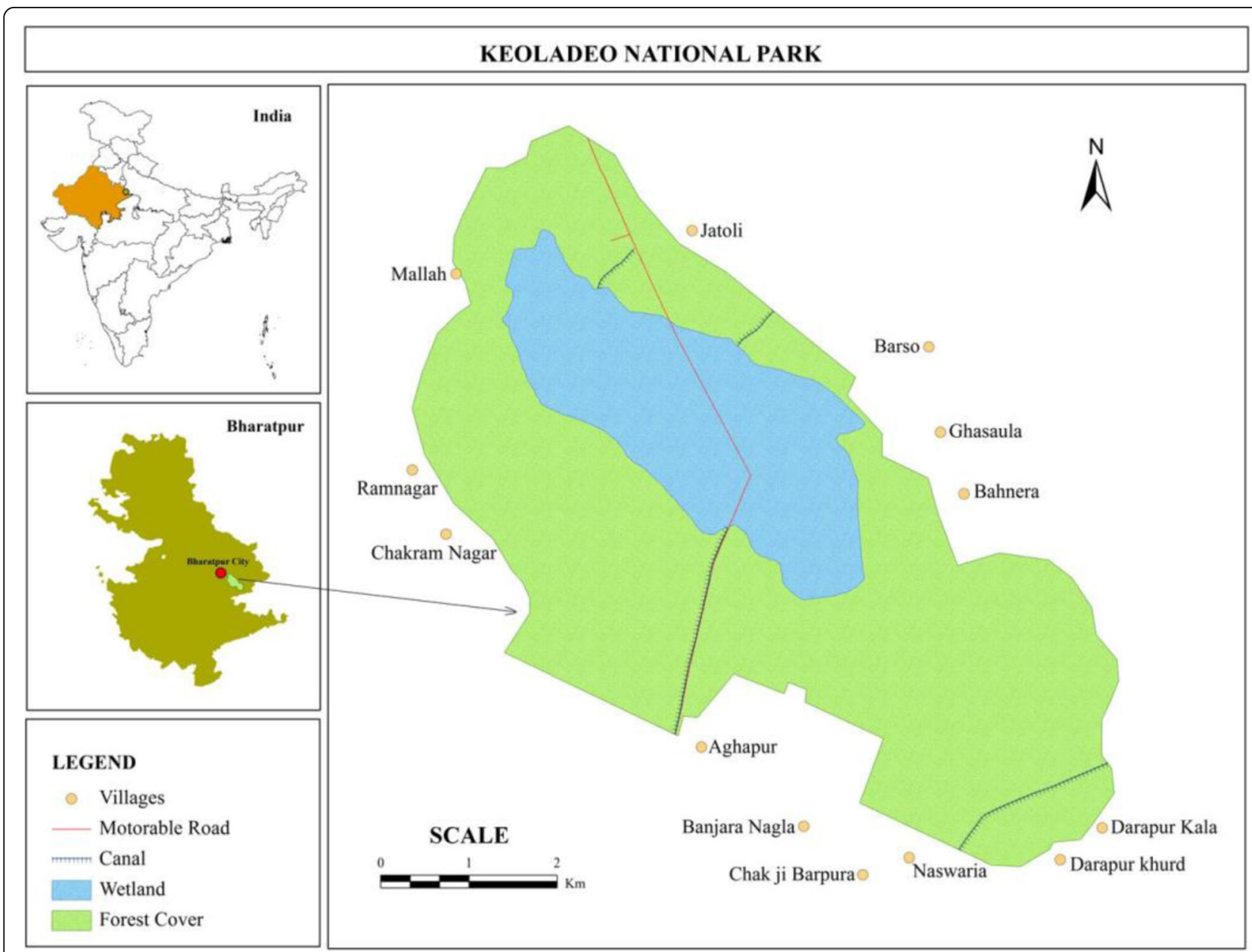

Fig. 1 Location of Keoladeo National Park and the neighboring villages (drawn based on Survey of India maps) (The wetland area has since changed in size and what is denoted here as forest cover is terrestrial vegetation) 
Table 1 Aspects covered in the questionnaire during the household survey

\begin{tabular}{|c|c|c|}
\hline S No & Particulars & Aspects covered \\
\hline 1 & $\begin{array}{l}\text { Background } \\
\text { information }\end{array}$ & $\begin{array}{l}\text { Family members, age, gender, } \\
\text { literacy, caste }\end{array}$ \\
\hline 2 & $\begin{array}{l}\text { Income and } \\
\text { occupations }\end{array}$ & $\begin{array}{l}\text { Primary and secondary occupations, } \\
\text { source of income of the family }\end{array}$ \\
\hline 3 & Households & Type of houses, area, ownership \\
\hline 4 & Agriculture & $\begin{array}{l}\text { Land holdings, ownerships, land use, } \\
\text { crops varieties, irrigation, use of } \\
\text { machinery and high yielding variety } \\
\text { seeds }\end{array}$ \\
\hline 5 & Livestock & $\begin{array}{l}\text { Number, types, income, decadal } \\
\text { change }\end{array}$ \\
\hline 6 & Health & $\begin{array}{l}\text { Disease, health facilities, duration, } \\
\text { frequency }\end{array}$ \\
\hline 7 & Fuel and fodder & Type, sources, consumption \\
\hline 8 & $\begin{array}{l}\text { Water and sanitation } \\
\text { facilities }\end{array}$ & $\begin{array}{l}\text { Source, type, portability and } \\
\text { associated problems }\end{array}$ \\
\hline 9 & Irrigation & $\begin{array}{l}\text { Source - Surface/groundwater, check } \\
\text { dams, water availability, agro-productivity }\end{array}$ \\
\hline 10 & $\begin{array}{l}\text { Environment and } \\
\text { natural resources }\end{array}$ & $\begin{array}{l}\text { Weather, trees and other vegetation } \\
\text { and resource availability }\end{array}$ \\
\hline 11 & $\begin{array}{l}\text { Opinions and } \\
\text { suggestions }\end{array}$ & $\begin{array}{l}\text { Open ended, covering other relevant } \\
\text { aspects }\end{array}$ \\
\hline
\end{tabular}

the Additional file 1: Table S1: The questionnaire template). From the clusters of houses (adjoining houses, 10-15 in number, mostly of relatives) in each village, randomly selected ones, representing each cluster as a subset, were visited. Structured interviews, as per the questionnaire, were conducted with the eldest member in the family who (with informed consent) responded $(N=118)$ to our introductory queries. Data on demography, literacy, water sources, crops, livestock and landuse were collected from the line departments (irrigation, agriculture, and forest) of the Government of Rajasthan and the Census of India (2011).

To understand the current linkages and state of resource dependency between the neighboring human settlements and the Park, data on various aspects related to socio-economic status and natural resources dependency was subjected to comparative trend analyses, taking off from an earlier study (Azeez et al., 1992) that examined issues relating to the dependency of the human settlements on KNP. For comparison, the same parameters that were considered earlier and the same methodology for data collection was adopted here. Three villages (Chakram Nagar, Barso, and Chak Ji Barpura) that were not covered earlier were included in the present study. Furthermore, change in population from 1991 to 2011 in Darapur Khurd and Banjara Nagla, and literacy rate in Chak Ji Barpura could not considered in the present analyses as the earlier details for those villages were not available. To ascertain the differences in the mean over time, we used Wilcoxon signed rank test for literacy rate, source of income and fuel use in 2 years (1991 and 2011) and Friedman rank test for groundwater level (1982, 2002 and 2012), households and population in 3 years (1991, 2001 and 2011). Regression and Pearson's correlations were used to relate crop productivity and use of chemical fertilizers. The analyses were conducted using R-project for statistical computing ( $\mathrm{R}$ i386 3.1.2) as used earlier by Zeeshan \& Azeez (2016).

\section{Results}

The study explores the changes in the state of the villages after the eventful ban of primarily grazing and fuel wood collection inside the KNP. It aims to elicit the changes in dependency of the villagers on the KNP subsequent to the ban basing on the parameters that are indicators of socio-economic changes. These parameters include population, literacy, households, sources of income, fuel usage, water availability (groundwater level), agro inputs and local traditional vocations.

As, per the latest census, there was 9,481 males and 8,681 females in the villages around the Park. The human population in the villages significantly increased from 1991 to $2011(P=0.0007)$. The decadal growth rate in population for the period for males and females in each village is given in Table 2. The number of houses in the villages increased significantly $(P=0.0002)$ during 1991-2011. The village Mallah was the highest in number of houses and Darapur Khurd the lowest (Fig. 2). Average literacy rate in the villages significantly increased $(169 \%, P<0.05)$, $94 \%$ for males and $67.8 \%$ for females (Table 2) during the last two decades. We found no significant change in income from the major occupations - salary, agriculture and livestock $(P>0.05)$ from 1991 to 2011. The average income of a family unit in the villages during the survey was Rs 3000/- per month (44.41 USD), four times higher than that before 1992 (Azeez, 1992), yet lesser than the national average Rs 5729 (84.80 USD) per month during 2012 - 2013 (Press Trust of India, 2013). Three kinds of fuel are in use in the villages, wood (43.3\%), dung cake (40.1\%) and LPG (15\%). In the case of groundwater, demand for domestic needs largely agriculture have increased, resulting in significant $(P<0.0001)$ fall in the groundwater level (Fig. 3). Compared to the situation in the late 1980s, in terms of occupation certain villages witnessed a rise in preference towards agriculture, while some villages have shifted to other occupations.

Bharatpur follows double cropping pattern of agriculture, Kharif (spring crop) and Rabi (summer crop). Kharif production decreased significantly $\left(R^{2}=0.432, P<0.05\right)$ from 1994 to 2011, whereas Rabi production increased significantly $\left(R^{2}=0.727, P<0.0001\right)$ from 1991 to 2011 (Additional file 1: Figure S2: Kharif crop production and 
Table 2 Population, literates and land under agriculture (in hectares) in 2011 in each village (increase in population and literacy from 1991 to 2011 given in percentage in parenthesis, based on Census of India, $M=$ male, $F=$ female, $T=$ total, I=irrigated, $U=$ un-irrigated, NA = Not available)

\begin{tabular}{|c|c|c|c|c|c|c|c|c|c|}
\hline \multirow[t]{2}{*}{ Village } & \multicolumn{3}{|l|}{ Population } & \multicolumn{3}{|l|}{ Literates } & \multicolumn{3}{|c|}{ land $(\mathrm{Ha})$} \\
\hline & M & $\mathrm{F}$ & $\mathrm{T}$ & M & $\mathrm{F}$ & $\mathrm{T}$ & 1 & U & $\mathrm{T}$ \\
\hline Aghapur & $1121(65.8)$ & $1097(93.4)$ & $2218(78.4)$ & $780(221)$ & $552(1126.7)$ & $1332(362.5)$ & 553 & 192 & 745 \\
\hline Chakram Nagar & 341 (78.5) & $292(79.1)$ & $633(78.8)$ & $201(240.7)$ & 77 (1825) & $278(341.3)$ & 67 & 9 & 76 \\
\hline Ramnagar & $549(42.9)$ & $513(48.6)$ & $1062(45.7)$ & $383(190.2)$ & $236(2045.5)$ & 619 (332.9) & 167 & 87 & 254 \\
\hline Mallah & $1840(-17.6)$ & $1644(-9.7)$ & $3484(-14.1)$ & $1286(59.4)$ & $678(1440.9)$ & 1964 (130.8) & 171 & 119 & 290 \\
\hline Jatoli & 693 (18.6) & $682(32.6)$ & $1375(25.2)$ & $538(96.4)$ & $294(740)$ & $832(169.3)$ & 87 & 23 & 110 \\
\hline Barso & $1221(43.4)$ & $1201(71)$ & $2422(56)$ & $921(102)$ & $622(615)$ & 1543 (178) & 180 & 68 & 248 \\
\hline Ghasaula & 798 (3.2) & $696(9.9)$ & $1494(6.3)$ & $566(68)$ & $316(2157.1)$ & 882 (151.3) & 256 & 170 & 426 \\
\hline Bahnera & $1621(44.7)$ & 1409 (51.6) & 3030 (47.9) & 1207 (81.2) & $760(322.2)$ & 1967 (132.5) & 408 & 204 & 612 \\
\hline Darapur Kala & 69 (53.3) & $63(46.5)$ & $132(50)$ & $61(144)$ & $29(480)$ & $90(200)$ & 196 & 57 & 253 \\
\hline Chak ji Barpura & $544(58.6)$ & $471(71.2)$ & 1015 (64.2) & 343 (NA) & 138 (NA) & 481 (NA) & NA & NA & NA \\
\hline Naswaria & $398(7.8)$ & 349 (26.9) & 747 (16.2) & $330(43.5)$ & $172(212.7)$ & $502(76.1)$ & 51 & 18 & 69 \\
\hline Banjara Nagla & 286 (NA) & 264 (NA) & 550 (NA) & 167 (NA) & $63(N A)$ & 230 (NA) & NA & NA & 123 \\
\hline
\end{tabular}

fertilizer application and S3: Rabi crop production and fertilizer application). Major crops raised were paddy, rice, jowar, bajra, rapeseed, mustard, maize, wheat, barley, green gram, moth beans, black gram, white chickpeas and groundnut. There has been an increase in fertilizer use in the area; in the early 1990s urea application was $30 \mathrm{~kg} / \mathrm{ha}$, while it was $90-120 \mathrm{~kg} / \mathrm{ha}$ in 2012 . Data from the Directorate of Economics and Statistics (Jaipur, Rajasthan) for 1991-2010 reveals that fertilizer use in Bharatpur has increased five times from 1991-1992 to 2009-2010 (Additional file 1: Figure S4: fertilizer use in Bharatpur), reflecting the intensification of agrochemical input in the area. Nitrogen $(\mathrm{N})$, phosphorus $(\mathrm{P})$ and potassium $(\mathrm{K})$ are the preferred chemical fertilizers, but $\mathrm{N}$ application is proportionately higher. NPK fertilizer usage increased significantly $\left(R^{2}=0.762, P<0.05\right)$ for Kharif and $\left(R^{2}=0\right.$. 876, $P<0.0001$ ) and Rabi (Additional file 1: Figure S2: Kharif crop production and fertilizer application and S3: Rabi crop production and fertilizer application). A two-tailed Pearson correlation test reveals fertilizer use as negatively correlated with Kharif production $(r=-0.878)$ and positively correlated with Rabi production $(r=0.844)$.

\section{Discussion}

The villages around the park have seen notable increase in the population. The population increase in the villages would have put pressure on natural resources, from rising demands especially for land, water, fuel and grains. Lands around the park are mostly agricultural (irrigated and un-irrigated) and privately owned. Human

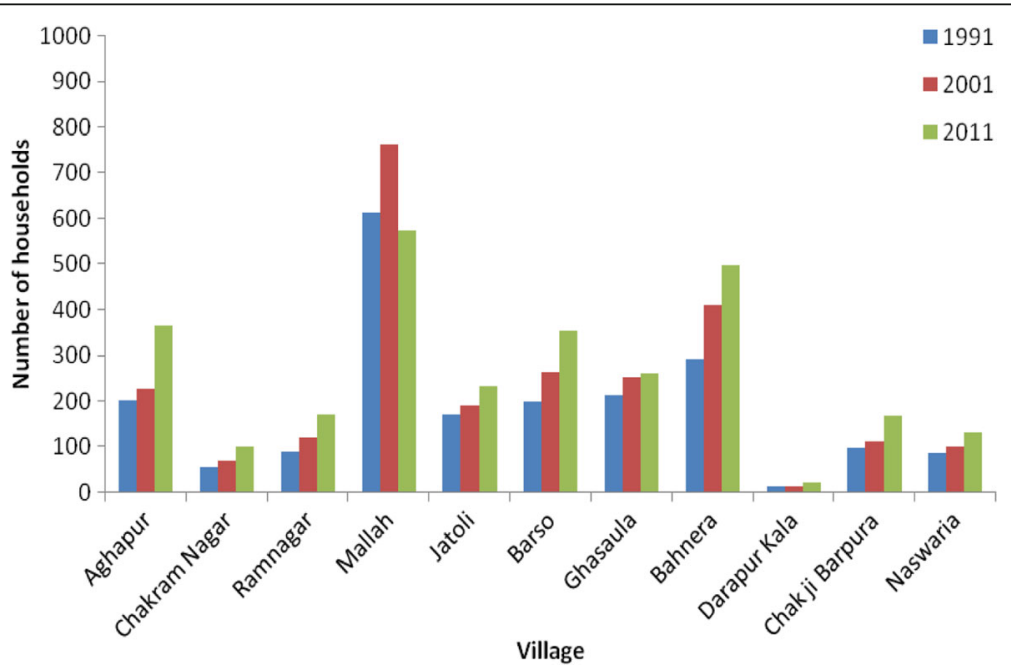

Fig. 2 Number of households in villages (Source: Census of India) 


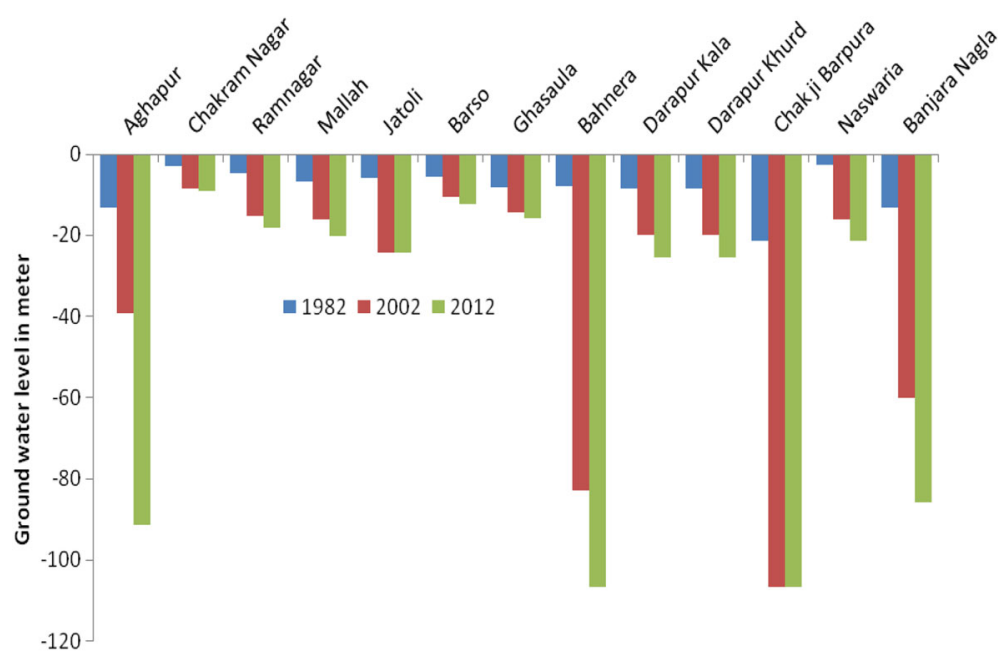

Fig. 3 Groundwater level from the surface level

population growth has a direct bearing on the agricultural land and the number of houses in each village. Consequent to increasing number of people the percapita parcel of land under agriculture has reduced. Rising population hikes the demand for quarters, as the joint families are giving way to the nuclear families, and increasingly family units (Husband, wife and kids) move out from the traditional joint family households. At earlier times, in the joint family system the male siblings, their wives, and children continued living in the same households. In the male-dominated families, the womenfolk rarely interact with elder males, even close relatives, covering their faces with their sari (a common apparel in India) while in public. The residences built are increasingly fanning out into agricultural lands. The increasing conversion of agriculture land to other uses (commercial or residential) would be a threat to agriculture and associated economy in near future. Nevertheless, flourishing realty ventures having a growing city adjacent have prompted many villagers to trade land and change occupation to gratify increasing demands. Switching land from agriculture to other purposes has also increased. It has been reported by many villagers that in recent years the land price in the area has gone up by many folds.

In each village, houses are placed in clusters towards a side of the cropland. Sanitation is a major issue in the villages, most also lacking proper drainage systems. Most villages have people from different castes. Dominant castes are Gujjar, Jat, Banjara, and Brahmins. Caste is an important factor determining the distribution of houses (Azeez et al. 1992). People from the same caste cluster together, segregated along caste-lines within the village. Castes lower in local social hierarchy stay towards the periphery of the village. The houses, based on construction and structure, are of three types. Kutcha houses made of mud, wood, straw, and leaves belong to poorer segments of the society. Pucca houses are strongly built with bricks, cement, steel, and wood, and are owned by middle to upper-class people. Semi-pucca houses are those houses built partially pucca and such houses belong to the lower middle class people. Of all the villages, Ramnagar has 100\% pucca houses while Chak ji Barpura has $100 \%$ semi-pucca houses. Almost all the pucca houses in the villages were built during the past two decades. The proportion of the pucca houses reflects better economic and social status of the villagers (Fig. 4).

The increase in literacy reflects better access to schools and associated amenities and better socioeconomic state of the people. In overall in the villages, $18.5 \%$ respondents were illiterate, $31.5 \%$ have completed primary school, $38.9 \%$ secondary school and $11.1 \%$ college education. The high rate of increase in literacy among males actually reflects a continuing trend of education being recognized as need for better life-quality and the females reflect the socio-economic emancipation and mainstreaming (getting into salaried employment and other socio-economic activities rather than being restricted to household conventional chores) of the girl child happening in the villages. People are inclined to and can now afford to send children to schools rather than engaging them in cattle grazing, agriculture and other rustic chores, as was the practice earlier. Literacy and further education make the people cognizant of alternative livelihoods and better lifestyles with lesser direct dependency on the KNP ecosystem, their nearest common property, for resources. Literacy, education and exposure incites people to change from being 'ecosystem people' to 'biosphere people' lesser reliant on the local ecosystem for their needs or the 'omnivores' of Gadgil \& Guha (1995) who categorized Indian population into 


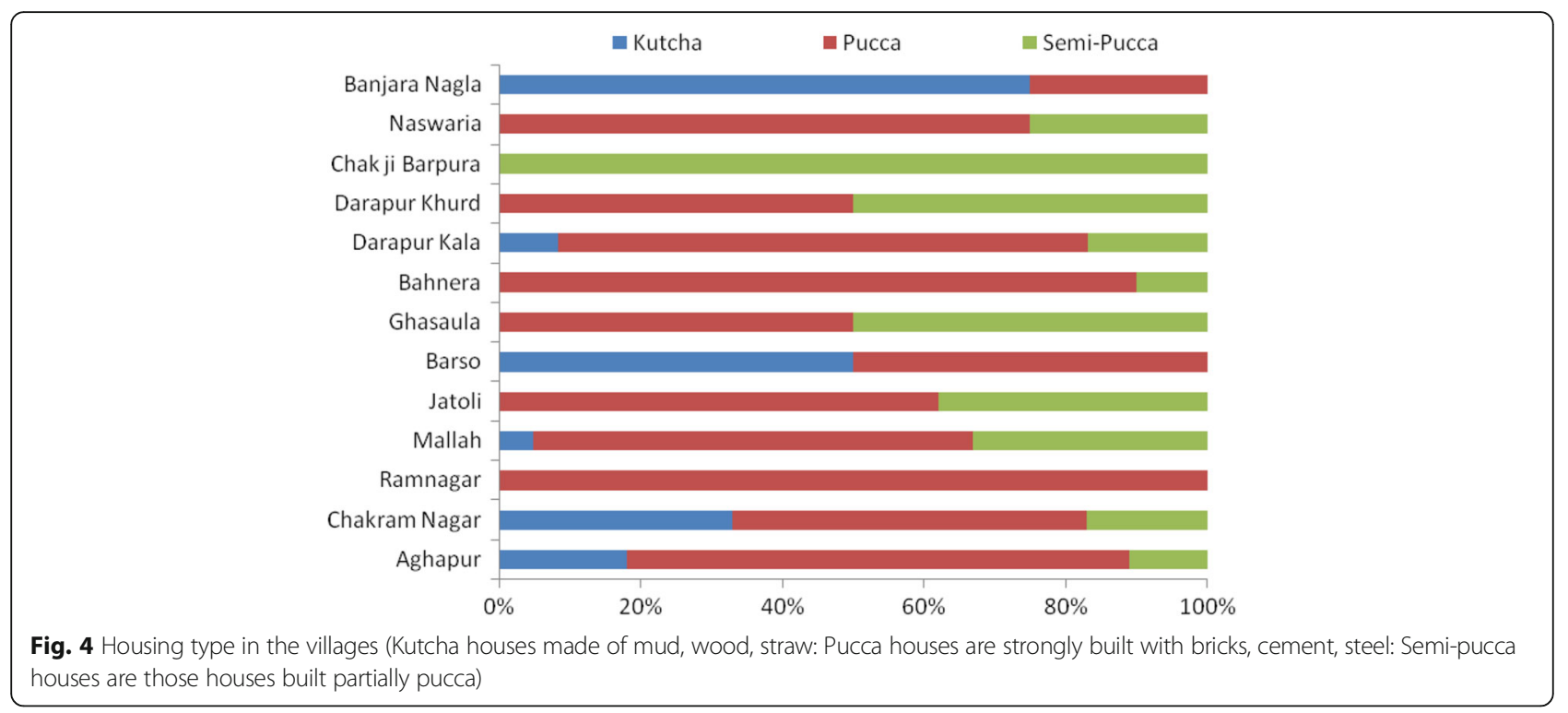

'omnivores, ecosystem people and ecological refugees'. The education system in schools plays a vital role towards environmental awareness (Barthwal, \& Mathur, 2012), although, the influence of the current curricula in India to make younger generation people convinced about the need for long-term environment protection remains doubtful.

\section{Sources of income}

The major sources of income, during the present survey, were agriculture $(45.3 \%)$, salary or wages $(40.9 \%)$, and livestock (13.7\%). As per the earlier study, the order in the source of income was salary/wages (42.8\%), agriculture (42.05\%) and livestock (15.2\%). The growing awareness among the people about industrial, private and government employment opportunities shape their desire to switch occupations. They also realize that depending entirely on agriculture is risky because of the associated uncertainties. Nevertheless, in several villages, agriculture still is the main source of income; in Ramnagar, the highest number of people are engaged in agriculture $(85.7 \%)$, while in Naswaria none is engaged in that sector. However, the data on income drew out from the questionnaire could be misleading because many respondents were apprehensive about revealing their real income. Overall, there is an increase in the proportion of salaried employees (Table 3). Of the villages, Chakram Nagar (83.3\%) had the highest and Ramnagar (14.3\%) the lowest number of people on salary/wages. The villagers earning more than one-fourth of income from livestock were Naswaria (50\%) and Mallah (26.1\%), and those villages with zero dependencies on livestock were Banjara Nagla, Ramnagar, Ghasaula, and Barso. It reflects that some of the livestock-rearing villages have stuck to their conventional occupation, while those with traditionally lesser livestock or agriculture have moved out of the profession relatively more. Of the 10 villages covered during the earlier study, the source of income for five villages has shifted from salary/wages to other occupations (Fig. 5) while in the rest of the villages the shift was towards salary/wages. The shift toward salary/ wages has been highest in Banjara Nagla (75\%) that traditionally had lesser agricultural lands and livestock. In Darapur Kala, there is a $52.4 \%$ fall in salary/wages than that of the late $1980 \mathrm{~s}$. In the past, $85.1 \%$ of the population in Mallah depended on salary or wages; but during the present study, it is only $43.4 \%$. It seems that many in the villages have found engagement in self-employment

Table 3 Percentage of the villagers depending on salary/wages, livestock, and agriculture as source of income

\begin{tabular}{llll}
\hline Village & Salary/wages & Agriculture & Livestock \\
\hline Aghapur & 33.33 & 57.14 & 9.53 \\
Chakram Nagar & 83.33 & 0 & 16.67 \\
Ramnagar & 14.3 & 85.7 & 0 \\
Mallah & 43.47 & 30.43 & 26.1 \\
Jatoli & 46.15 & 46.15 & 7.7 \\
Barso & 50 & 50 & 0 \\
Ghasaula & 50 & 50 & 0 \\
Bahnera & 30 & 60 & 10 \\
Darapur Kala & 30.76 & 53.84 & 15.4 \\
Darapur Khurd & 36.36 & 45.45 & 18.19 \\
Chak ji Barpura & 46 & 49 & 5 \\
Naswaria & 50 & 0 & 50 \\
Banjara Nagla & 75 & 25 & 0 \\
\hline
\end{tabular}




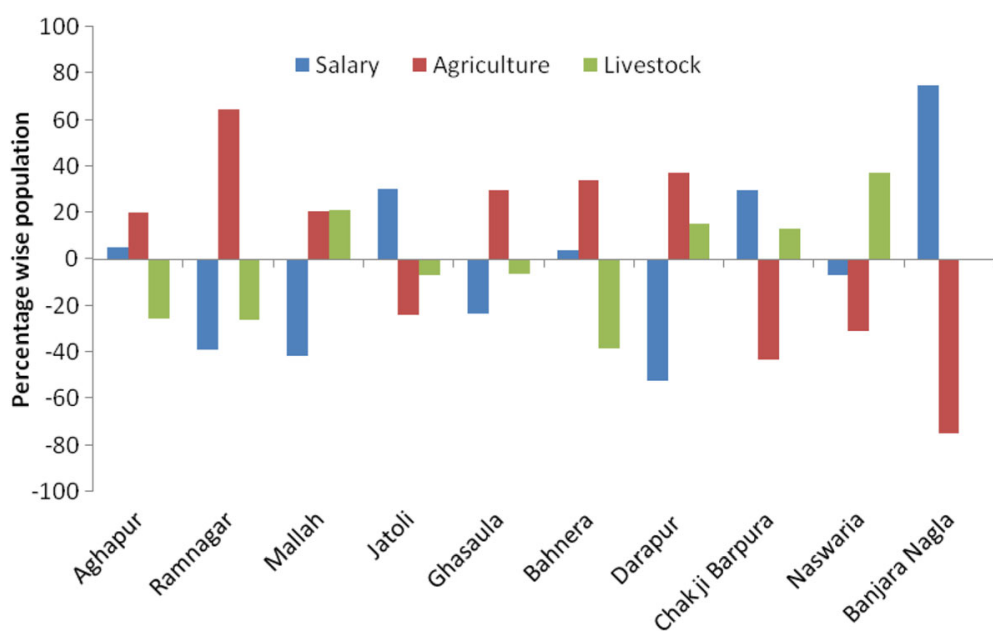

Fig. 5 Shift in the source of income of the villagers during 1991-2012

and trades, with increasing spread of the city to their neighborhood. Increasing potential of the area as a tourist destination also would have catalyzed this change and diversified their occupations.

Traditionally, livestock has been an important source of livelihood in most of the villages. The villagers used to leave their cattle and buffaloes in the KNP for weeks and months. Since the entry of livestock into KNP for grazing was banned in the early 1980s, villagers were forced to take cattle to grazing lands in neighboring Dholpur district, a long journey that has increasingly become difficult. The inaccessibility to grazing lands and fodder being a major factor, conjointly with other developments in the area such as increasing tourism, education, and exposure, there has been a paradigm shift in the preference of villagers towards other means of income than their traditional ones. Consequently, the dependency of the villages on livestock for income has become less. Bahnera (38.1\%) tops the list of villages leaving livestock. Naswaria (37.5\%) tops the list of those who are shifting towards livestock (Fig. 5) perhaps for the rising need of milk in the growing city and outskirts. This would also mean a shift in their practice of livestock rearing, from free ranging to stall-feeding, and consequent need for fetching fodder and feed from elsewhere, market or other sources. Furthermore, livestock occupies traditional importance in the socio-economic milieu of the bucolic life. Some villagers reportedly smuggle their cattle to the KNP through breaches in the boundary walls for grazing. Many of the villagers expressed their misgivings about the ban on grazing since they view grazing as their historical right.

\section{Fuel and water}

In the late 1980 's, dung cake met $60.7 \%$ to the fuel needs while wood was meeting only $39.3 \%$. Now, wood contributed highest to the fuel used in the villages (Table 4). These include agricultural wastes (straw etc.) and branches of trees and shrubs and that procured from the market. Of all the villages, Ramnagar (71.4\%) was highest in the use of wood, while Bahnera (18.2\%) was the lowest. Crop waste and twigs are largely used by economically backward members holding no livestock. The use of dung cake decreased significantly $(P=0.006)$ across the years. Dung cake, usually prepared by females in the family, is an important fuel by tradition. Darapur (50\%) was the highest in dung cake use and Barahpura $(10 \%)$ the lowest. LPG, not in use earlier in the villages, was found increasing in use significantly $(P=0.02)$; it now accounts for $15.0 \%$ of the total fuel used. Except for Banjara Nagla, Naswaria, and Ramnagar, the other villages use LPG for cooking. Barahpura has the highest users $(40 \%)$ and Ghasaula the lowest (10\%). The increased use of LPG in the villages could be because of the initiatives by the government to provide access to clean fuels, subsidies, and popularizing measures, and

Table 4 Usage (in \%) of different types of fuel in the villages

\begin{tabular}{|c|c|c|c|c|c|c|}
\hline \multirow[t]{2}{*}{ Village } & \multicolumn{2}{|c|}{ Wood (\%) } & \multicolumn{2}{|c|}{ Dung cake (\%) } & \multicolumn{2}{|c|}{ LPG (\%) } \\
\hline & 1991 & 2012 & 1991 & 2012 & 1991 & 2012 \\
\hline Aghapur & 30.7 & 35.29 & 69.3 & 47.07 & 0 & 18 \\
\hline Ramnagar & 34.6 & 71.42 & 65.4 & 28.57 & 0 & 0 \\
\hline Mallah & 23 & 36.36 & 77 & 40.92 & 0 & 23 \\
\hline Jatoli & 39.4 & 38.46 & 60.5 & 46.16 & 0 & 15 \\
\hline Ghasaula & 35 & 50 & 65 & 40 & 0 & 10 \\
\hline Bahnera & 36.2 & 28.18 & 63.8 & 45.45 & 0 & 27 \\
\hline Darapur Kala & 29.2 & 33.33 & 70.8 & 50.01 & 0 & 17 \\
\hline Chakji Barpura & 62.8 & 50 & 37.3 & 10 & 0 & 40 \\
\hline Naswaria & 43.8 & 50 & 56.3 & 50 & 0 & 0 \\
\hline Banjara Nagla & 58.3 & 50 & 41.7 & 50 & 0 & 0 \\
\hline
\end{tabular}


the increasing realization among the locals of ease of its use. Furthermore, with the tendency in occupation from agriculture and livestock-based economy to salaried jobs, getting crop waste, wild wood and dung cakes is increasingly difficult.

Earlier, surface water was important for irrigation; lately, it is becoming inadequate for domestic and agriculture use. Surface water in the wetlands of the KNP serves to maintain the groundwater level and quality in the surroundings (Azeez et al. 2000). However, this important ecosystem provisioning service (TEEB, 2010) requires enough supply of water to the wetlands. For the past 2 decades, the KNP suffer serious scarcity of water and low supply from its usual sources such as Panchna dam.

\section{Agriculture}

Agriculture is an important source of income and at times, villagers suffer loss due to erratic, low rainfall and power deficit for ground water irrigation. With the increasing cost for lifting ground water, the price yielded from crops is short to cover the expenses. The vagaries in the returns from agriculture force the people to scout for other occupations as a cushion. The villagers perceive that other avenues such as business and employment provide better earnings, as evident from the shift in the principal source of income in some of the villages. Changes in their lifestyle also make the villagers look towards the neighboring city for gainful activities. Educated people have almost completely exited from agriculture or livestock as their key occupation. The village which showed preference towards agriculture was Ramnagar (64.7\% increase), while the village that moved away was Darapur [37.04\% decline, (Fig. 5)]. In Banjara Nangla, $75 \%$ of the villagers shifted from agriculture, the highest $(100 \%)$ occupation in the village in 1991, to salaries/wages.

The last three decades witnessed a shift in crops, the cash crops replacing food crops, a move towards better returns. In many villages, conventional multi-cropping (green gram, wheat, and mustard) has given way to double crops (wheat and to a larger extend mustard). Use of new farming techniques [tractors, high yielding varieties (HYV) and chemical fertilizers] has also increased. Progressing drop in the groundwater levels has made the cost of irrigation high as deeper bore wells are required to irrigate the farmlands adequately. Rapeseed and mustard require lesser water and nutrients, especially nitrogen and phosphorous, for growth and seed formation (Premi \& Kumar, 2004). Wheat requires flood irrigation four times per season, whereas mustard requires only twice.

Located amidst a human inhabited and agricultural landscape, KNP is likely to be affected by the agriculture practices in the surroundings. The soil in the area is alkaline and lack essential nutrients such as nitrogen and phosphorous. Fertilizers (urea and di-ammonium phosphate) meet these requirements. The prescribed usage of $\mathrm{N}$ fertilizer in the crop is $80 \mathrm{~kg} / \mathrm{ha}$ (Parihar 2004). An increase in production was seen when 70 $80 \mathrm{~kg} / \mathrm{ha}$ the fertilizer is applied. While the higher application of $\mathrm{N}$ fertilizer increased crop production from 1999 to 2000, it resulted in a reduction in 2007 and 2008. Sneva (1977) reported that addition of $\mathrm{N}$-fertilizer above $56 \mathrm{~kg} / \mathrm{ha}$ leads to a buildup of $\mathrm{NO}_{3}-\mathrm{N}$ just above the cemented caliches layer that significantly increases the residues in the subsurface soil and deeper horizons in the soil profile. This prevents proper drainage in the soil because rainfall in the area is low for notable leaching and evacuation, and the presence of an impervious layer would further reduce it. Accumulation of $\mathrm{NO}_{3}-\mathrm{N}$ at a depth below the primary rooting zone would lead to restricting the supply of $\mathrm{N}$ to plants (Sneva, 1977), reducing crop productivity. The reduction of productivity in later years seen in the area would be perhaps for these reasons.

Over the years, the frequency of pest and disease outbreaks in crops has reportedly increased. With inadequate water supply, termites raid wheat. Another pest, powdery mildew also infests mustard. To contain the pest outbreaks, insecticides such as DDT, BHC, Aldrin, Dieldrin, Endrin, Endosulfan and herbicides such as 2,4Dichlorophenoxyacetic Acid is used. Endosulfan has been banned for manufacture and uses under Stockholm convention in April 2011 for its human and environmental implications. More than 75 countries have banned it, even prior to the ban was agreed upon at the Convention. However, it is still used in India, China, and a few other countries. Aldrin and Dieldrin have been banned in India since 2003 (Mustafa et al. 2010). Monocrotophos was also used in the crop fields around KNP, and there were incidences of bird mortality (Sarus crane Grus antigone and common crane Grus grus) due to chemical poisoning (Vijayan, 1991, Muralidharan, 1993, Pain et al., 2004). The intensive use of agrochemicals has always been a serious threat to the KNP (Bhadouria et al. 2012). Most of the birds go out of the KNP to feed in the agricultural fields or satellite wetlands (Bhupathy, 1991; Sundaramoorthy 1991). The birds feeding outside possibly ingest a considerable quantity of these toxic agrochemicals.

\section{Villagers and KNP}

The decision to ban all activities in the KNP was not acceptable to the villagers due to their high dependence on the KNP and their traditional rights for the same. Wood is necessary as fuel in high quantities for many social functions and daily use. Uncontrolled exploitation of fuel 
wood from the KNP have certainly withered the natural wilderness and promoted invasive species, especially Prosopis juliflora. In recent years, such species have become a serious threat to the park ecosystem (Anoop, 2010, Grewal, 2011, Hiremath \& Sundaram, 2013). Since 2009, the management has taken up its eradication program (Anoop, 2010), wherein members from the surrounding villages are involved. In each village, a committee is assigned an area in the KNP for operation. The villagers, supervised by a committee, are allowed to take away the wood, which would complement their fuel needs. The program has been successful largely for the involvement of the villagers with the conservationoriented program of the forest department benefitting both the KNP and the villagers.

People, mainly from the lower middle and middle class, used to rear buffaloes and cows extensively for milk and dung. A few also keep sheep and goat and those from the lower class rear pigs. The ban on grazing in the KNP has led to a fall in livestock population, especially of those free-ranging ones. Ecologically a wetland is a transition ecosystem and it is also the most productive ecosystem. The high biomass production has to be removed by appropriate consumers to maintain the ecological quality of a wetland. In KNP, the livestock especially buffalos from nearby villages served this purpose. Currently, the number of mammalian consumers in the KNP is low, leading to gross accumulation of biomass. On an average, a buffalo removes $20-28 \mathrm{~kg}$ of wet biomass. It also tramples and churns the wetland and cause the formation of submerged tracks for fishes and open water for water birds (Gulickx et al. 2007). Herbivores are selective feeders (Middleton, 1999); hence, increase the heterogeneity of wetlands. Thus, removal of buffaloes had serious repercussion on the ecology of the KNP in terms of biomass accumulation, reduction in open water area and an overall reduction in the heterogeneity of habitats. For the villagers, besides the dearth of fodder and pastureland, the scarcity of water since the last decade made maintaining livestock difficult. They perceive well that livestock improved their economy as well as the biodiversity in the surroundings. Many villagers judge that livestock provided ecosystem (provisioning) services to birds, for species such as Painted Stork, Asian Openbill stork, Blackheaded Ibis, Glossy Ibis, Eurasian Spoonbill, Indian Cormorant and Little Cormorant feed on organisms growing in the churned-up wetlands and offered openwater habitats for waterfowl especially diving and dabbling ducks.

For the last two decades, water flowing into KNP from once perennial rivers Banganga and Gambhir has stopped due to the intense water use in its upper reaches (Zeeshan \& Prusty, 2014). People opine that stone quarrying in the catchment for the last 4 to 5 decades is a major threat to the rivers (Zeeshan et al. 2013; Zeeshan \& Prusty, 2014). More than $90 \%$ of the forest in the area has been reportedly lost due to mining. Disputes on forest and revenue lands among the concerned departments are also supposedly reasons for deforestation. Check dams upstream are also a reason for water scarcity in the downstream area. Since the last two decades, 26 check dams were built in five upstream villages, with the highest number (15) in the Barkhera village (Zeeshan \& Prusty, 2014). Thus, these landscape level changes and an increase in upstream storages has reduced water flow in downstream areas that includes the KNP. The water needs of ecosystems have been largely compromised due to social and political pressures, such as growing demand for water in domestic and agricultural uses in the upstream area. Political leaders have taken up such issues to various statutory bodies. They also exert their influence on the executive agencies. In effect, the scarcity of water threatens the biodiversity of KNP; however, the KNP management through the Government of Rajasthan has received funds from Planning Commission (Government of India) to get water from an alternative source. Recently, water is being supplied to the KNP from the river Chambal.

Improvement in people's livelihood in the periphery of PAs remains debatable. A recent study concludes that job opportunities due to PAs are not always fairly distributed among the locals (Mohammed, 2015), with several factors coming into play. In the case of KNP, we found that priorities to ensure protection and conservation have forced a general change in the source of income of people living in the surroundings rather than directly improving their economic status (Additional file 1: Figure S5: Income from Salary/Wages (S), Agriculture (A) and Livestock (L)). Protection and conservation strategies played a vital role in biodiversity conservation of the KNP. It attracts researchers, nature enthusiasts and tourists from across the globe, which in turn, has helped the economy of the Bharatpur city. Several locals are engaged as tourist/nature guides, cycle-rickshaw operators, field assistants and in hospitality services for tourists and others. However, looking at the realized tangible benefits, several villagers are skeptical about the utility of the KNP for them; perhaps they do not value the indirect benefits and direct values for them are negligible. It was reported that KNP is important in maintaining the groundwater level and quality in the surroundings (Azeez et al., 2000), which many of the villagers currently acknowledge. Ban on grazing in the KNP was the policy decision that turned to be the vital local driver for the changes in the socio-economic status of the villagers around the Park. 
The World over, it has been found difficult to substantiate claims about the effects of PAs on the local people due to the absence of baseline data during the pre-protected period and differences in subjective indicators of pre and post-protected period observations (Ferraro, 2008) and the absence of control communities. Even those studies relating poverty levels in the neighborhoods and the PAs (Ferraro 2002; Coad et al. 2008; de Sherbinin, 2008) do not bring out explicit causal linkages with protection as they fail to capture direct measure of socioeconomic wellbeing and control for confounding effects of geographic and other baseline characteristics (Igoe et al. 2008; Shoo, 2008; Joppa et al., 2009). In the present study, for the absence of control communities, it is difficult to distinguish between the changes happening at macro-level (in wider area, at the regional or national level) and the changes at the micro-level (in nearby villages) specifically due to the change in conservation governance of the KNP. A study on a PA in the same state as KNP concludes that conservation approach posed a threat to the livelihood in the periphery (Torri, 2011). The net impact of PAs on poverty by virtue of their location could be positive or negative (Adams et al., 2004; Scherl, 2004; Agrawal, \& Redford, 2006; Wilkie, et al., 2006) depending upon the local conditions. However, well-managed PAs can help in improving the livelihood of the local populace by promoting tourism and improving Infrastructure (Andam et al. 2010; Sims, 2010). In the case of KNP, it could not be substantiated if it has specifically improved livelihood in the neighboring communities. However, the ban on grazing has forced changes in the state of affairs; the villagers' dependency on the KNP, though biomass removal is almost a bygone matter and the KNP management has to look for other means to maintain the system and heterogeneity of microhabitats an essential ecological feature to accommodate large variety of faunal species including birds. Heterogeneity of habitats such as open-water, submerged and emergent vegetation, terrestrial vegetations appropriate for resting and roosting of birds, and a range of water depths are important for diverse fauna. In due course of time, the habitat heterogeneity in the park has reduced. In view of the resultant challenge to the local village economy, villagers were forced to reconcile with other means of livelihood. Eventually, they apparently have liberated themselves from their major direct dependency on resources from the PA. However, they acknowledge their indirect dependency, the linkage of ground water with its wetland and the economic improvement of the surroundings for the existence of the KNP. The protection strategy adopted at KNP thus had evident impacts on the villages in its periphery.

\section{Conclusion}

Involvement of local inhabitants in the periphery of PAs is believed to be vital for effective management of PAs and its conservation. It is considered advisable that the conservation governance has to draw the locals into participation in conservation actions. It would help in reconciling the conflicts of interests and in developing effective policies to care for the ecological milieu, ecosystem services, wildlife as well as the requirements and aspirations of the people around. Unlike most other PAs, KNP has limited resources to support livelihood for local villagers due to its size. Hence, guarding KNP against direct human use seems to the only choice at that time to ensure its long-term sustenance. In that context, the ban of grazing and other direct use executed in the early eighties has prompted the people to wean off from their dependency on the KNP. Socio-economic changes indicate that the action strengthening protection of KNP has been one of the drivers of the change for people in the periphery. Our study found no significant change in their source of income; though, we observed significantly lesser dependency on the KNP for their traditional direct requirements. However, the benefit of the ban to the KNP remains debatable in view of the amassing biomass in the wetland and invasion of colonizing species that need to be removed for the better ecological health of the system.

\section{Additional file}

Additional file 1: Table S1. The questionnaire template used to conduct household survey in the village neighbouring Keoladeo National Park (KNP). Figure S1. Location of Gambhiri river, Panchana dam, KNP and Bharatpur city (source Frank, 2011). Figure S2. Kharif production and fertilizer application in Bharatpur. Figure S3. Rabi production and fertilizer application in Bharatpur. Figure S4. Proportion of fertilizer use in Bharatpur across the years. Figure S5. Income from Salary/Wages (S), Agriculture (A) and Livestock (L) from 1991 to 2012. (DOC $1190 \mathrm{~kb}$ )

\section{Acknowledgements}

We are grateful to the Planning Commission of India for financial assistance. We are also grateful to Dr. Khyati Mathur IFS (then Director, KNP) and Mr. KR Anoop IFS (Rajasthan Forest Department) for support. We acknowledge the assistance by Ms. Natasha Shrivastava during the fieldwork. We thank our local assistant Mr. Pajji Singh (Jatoli Village, Bharatpur) and other villagers for their support and cooperation during the surveys. We are thankful to Ms. Alyssa M. Fontanilla (University of Philippines) for comments on the draft of the paper. We also thank Mr. Mohammed Ibrahim (SACON), for help in refining the study area map.

\section{Authors' contribution}

MZ designed the research, collected and analyzed data, and wrote the paper. BAKP \& PAA contributed to design of the study, data analysis, interpretation and manuscript writing. All authors read and approved the final manuscript.

\section{Competing interests}

Mr. Mohd Zeeshan worked as a research fellow on the project sanctioned by Planning Commission, Government of India. The data used in the paper was collected while working for the project. Dr B Anjan Kumar Prusty and Dr P A Azeez supervised the work. We do not have a conflict of interest in the manuscript. 


\section{Publisher's Note}

Springer Nature remains neutral with regard to jurisdictional claims in published maps and institutional affiliations.

\section{Author details India. \\ Received: 8 July 2016 Accepted: 27 March 2017 \\ Published online: 07 April 2017}

'Sálim Ali Centre for Ornithology and Natural History (SACON), Anaikatty (PO), Coimbatore 641108, Tamil Nadu, India. ${ }^{2}$ Environmental Impact Assessment Division, Gujarat Institute of Desert Ecology (GUIDE), Post Box No. - 83Opp. Changleshwar Temple, Mundra Road, Bhuj 370001, Gujarat,

\section{References}

Adams WM, Aveling, R., Brockington, D., Dickson, B., Elliott, J., Hutton, J., ... \& Wolmer, W (2004) Biodiversity conservation and the eradication of poverty. Science 306(5699):1146-1149

Agrawal A, Redford K (2006) Poverty, development, and biodiversity conservation: Shooting in the dark? Ann Arbor Ml 48109(734):647-5948

Andam KS, Ferraro PJ, Sims KR, Healy A, Holland MB (2010) Protected areas reduced poverty in Costa Rica and Thailand. Proc Natl Acad Sci 107(22): 9996-10001

Anoop KR (2010) Progress of Prosopis juliflora eradication work in Keoladeo National Park, Unpublished Report, Rajasthan Forest Department

Arrow KJ, Fischer AC (1974) Environmental preservation, uncertainty and irreversibility. Q J Econ 88(2):312-319

Azeez PA (1992) Conservation and socio-economic conflicts. The Green Age 1(1): 26-29

Azeez PA, Ramachandran NK, Vijayan VS (1992) The socio-economics of the villages around Keoladeo National Park, Bharatpur (Rajasthan), India. Int J Ecol Environ Sci 18:169-179

Azeez PA, Nadarajan NR, Mittal DD (2000) The impact of a monsoonal wetland on groundwater chemistry. Pollut Res 19(2):249-255

Barthwal SC, Mathur VB (2012) Teachers' Knowledge of and Attitude towards Wildlife and Conservation: A Case Study from Ladakh, India. Mt Res Dev 32(2):169-175

Bhadouria BS, Mathur VB, Kaul R (2012) Monitoring of organochlorine pesticides in and around Keoladeo National Park, Bharatpur, Rajasthan India. Environ Monit Assess 184:5295-5300

Bhupathy S (1991) Population and resource utilization of waterfowl in Keoladeo National Park, Bharatpur, (Doctoral dissertation, Ph. D. Thesis, Rajasthan University, Jaipur)

Brockington D, Igoe J, Schmidt-Soltau KAl (2006) Conservation, human rights, and poverty reduction. Conserv Biol 20(1):250-252

Bruner AG, Gullison RE, Rice RE, da Fonseca GAB (2001) Effectiveness of parks in protecting tropical biodiversity. Science 291:125-128

Census of India (2011) Census of India, Ministry of Home Affairs Government of India., Retrieved from http://censusindia.gov.in/

Chape S, Harrison J, Spalding M, Lysenko I (2005) Measuring the extent and effectiveness of protected areas as an indicator for meeting global biodiversity targets. Philos Trans R Soc B 360(1454):443-455

Cincotta RP, Wisnewski J, Engelman R (2000) Human population in the biodiversity hotspots. Nature 404:990-992

Coad L, Campbell A, Miles L, Humphries K (2008) The costs and benefits of protected areas for local livelihoods: a review of the current literature. UNEP World Conservation Monitoring Centre, Cambridge

Convention on Biological Diversity (2010) The Strategic Plan for Biodiversity 2011 2020 and the Aichi Biodiversity Targets, UNEP/CBD/COP/DEC/X/2., Available at: www.cbd.int/doc/decisions/cop-10/cop-10-dec-02-en.pdf

de Sherbinin A (2008) Is poverty more acute near parks? An assessment of infant mortality rates around protected areas in developing countries. Oryx 42(01):26-35

DeFries R, Karanth KK, Pareeth S (2010) Interactions between protected areas and their surroundings in human-dominated tropical landscapes. Biol Conserv 143(12):2870-2880

Deguignet M, Juffe-Bignoli D, Harrison J, MacSharry B, Burgess N, Kingston N (2014) United Nations List of Protected Areas. UNEP-WCMC, Cambridge

Ferraro PJ (2002) The local costs of establishing protected areas in lowincome nations: Ranomafana National Park, Madagascar. Ecol Econ 43(2): $261-275$
Ferraro PJ (2008) Protected areas and human well-being. In: Conference, Economics and Conservation in the Tropics: A Strategic Dialogue, Conservation Strategy Fund, January

Frank AM (2011) Keoladeo National Park: highlighting surface water tensions. Interdiscip Environ Rev 12(3):231-243

Gadgil M, Guha R (1995) Ecology and equity - the use and abuse of nature in contemporary India., p 213, Penguin books, Reprinted in 2014

Grewal B (2011) Bharatpur - Can we Regain this Bird Paradise?., http://www. conservationindia.org/articles/bharatpur-can-we-regain-this-bird-paradise, Accessed on 12 Sept 2016

Gujja B (1995) Participatory management planning for the Keoladeo National Park, Bharatpur., Retrieved from: http://www.ramsar.org/sites/default/files/ documents/pdf/lib/hbk4-07cs08.pdf

Gulickx MMC, Beecroft RC, Green AC (2007) Introduction of water buffalo Bubalus bubalis to recently created wetlands at Kingfishers Bridge, Cambridgeshire, England. Conserv Evid 4:43-44

Hiremath AJ, Sundaram B (2013) Invasive plant species in Indian protected areas: conserving biodiversity in cultural landscapes. In: Plant Invasions in Protected Areas. Springer, Netherlands, pp 241-266

Igoe J, Brockington D, Randall S, Scholfield K (2008) Lessons to be learned about migration around protected areas (eLetter). Science. http://discovery.ucl.ac. uk/163466/

Joppa LN, Loarie SR, Pimm SL (2009) On population growth near protected areas. PLoS ONE 4(1):e4279

Jung, S. B (2015) Why India needs a conservation act, The Hindu Daily., Retrieved from http://www.thehindu.com/opinion/open-page/open-page-why-indianeeds-a-conservation-act/article6751901.ece

Krutilla JV (1967) Conservation reconsidered. Am Econ Rev 57(4):777-786

Middleton BA (1999) Succession and herbivory in monsoonal wetlands. Wetl Ecol Manag 6:189-202

Ministry of Environment \& Forests (2013) Protected Area Network., Retrieved on $15^{\text {th }}$ March 2015 from http://envfor.nic.in/public-information/protected-areanetwork

Mohammed I (2015) Terrestrial protected areas and poverty reduction in Ghana: A case study of the Mole National Park and the Mognori and Murugu communities. J Sustain Dev Stud 8(1):129-192

Mulongoy K, Chape S (2004) Protected areas and biodiversity: An overview of key issues. UNEP-WCMC, pp 1-52, Retrieved from http://www.ourplanet.com/ wcmc/pdfs/protectedareas.pdf. Accessed 15 July 2015

Muralidharan S (1993) Aldrin poisoning of Sarus cranes (Grus antigone) and a few granivorous birds on Keoladeo National Park, Bharatpur, India. Ecotoxicology 2:196-202

Mustafa M, Pathak R, Tripathi AK, Ahmed RS, Banerjee BD (2010) Maternal and cord blood levels of aldrin and dieldrin in Delhi population. Environ Monit Assess 17(1-4):633-638

Pain DJ, Gargi R, Cunningham AA, Jones A, Prakash V (2004) Mortality of globally threatened Sarus Cranes Grus antigone from monocrotophos poisoning in India. Sci Total Environ 326:55-61

Parihar SS (2004) Effect of crop establishment method, tillage, irrigation and nitrogen on production potential of rice (Oryza sativa L.) - wheat (Triticum aestivum L.) cropping system. Indian J Agron 49:1-5

Premi OP, Kumar M (2004) Response of Indian mustard (Brassica juncea) to different levels of nitrogen and phosphorus under irrigated condition. Indian J Agric Res 38(2):151-153

Press Trust of India (2013) India's per capita income rises to Rs 5,729 per month, Business Standard., Retrieved from http://www.business-standard.com/article/ economy-policy/india-s-per-capita-income-rises-to-rs-5-729-per-month113020700995_1.html

Prusty BAK, Chandra R, Hussain MS, Azeez PA (2011) Annual recruitment pattern of fishes into Keoladeo National Park wetland system, India. Environ Res 4(5-6):515-531

Prusty BAK, Zeeshan M, Shrivastava N (2013) Review of state of environment in Keoladeo National Park, Bharatpur, Rajasthan and its catchment area: A historical analysis (Planning Commission Division Report)., p 135

Pullin AS, Bangpan M, Dalrymple S, Dickson K, Haddaway NR, Healey JR, Hauari H, Hockley N, Jones JPG, Knight T, Vigurs C, Oliver S (2013) Human well-being impacts of terrestrial protected areas. Environ Evid 2:19

Redpath SM, Guti'Errez RJ, Wood KA, Young JC (2015) Finding a way out of conservation conflicts. In Book: Conflicts in Conservation: Navigating towards Solutions. Cambridge University Press British Ecological Society, Chapter 20, pp. 287-300. doi:10.1017/9781139084574.021 
Scherl LM, et al. (2004). Can protected areas contribute to poverty reduction? Opportunities and limitations. IUCN, Gland, Switzerland and Cambridge, UK. viii + 60pp

Schreckenberg K, Franks P, Martin A, Lang B (2016) Unpacking equity for protected area conservation. Parks 22(2):11-26. doi:10.2305/IUCN.CH.2016. PARKS-22-2KS.en

Shoo LP (2008) A balance between protected lands and population growth. Science 321:1-2

Shukla VP (1998) Modelling the dynamics of wetland macrophytes: Keoladeo National Park wetland, India. Ecol Model 109(1):99-114. doi:10.1016/503043800(98)00012-X

Sims KRE (2010) Conservation and development: Evidence from Thai protected areas. J Environ Econ Manag 60(2):94-114

Sneva FA (1977) Correlation of precipitation and temperature with spring regrowth, and mature crested wheatgrass yields. J Range Manag 30:270-275

Sundaramoorthy T (1991) Ecology of terrestrial birds in Keoladeo National Park, Bharatpur, (Doctoral dissertation, Ph. D. Thesis, University of Bombay)

TEEB (2010) Mainstreaming the economics of nature: a synthesis of the approach, conclusions and recommendations of TEEB. The Economics of Ecosystems and Biodiversity. pp. 1-36. http://www.teebweb.org/publication/ mainstreaming-the-economics-of-nature-a-synthesis-of-the-approachconclusions-and-recommendations-of-teeb/

Torri MC (2011) Conservation, relocation and the social consequences of conservation policies in protected areas: Case study of the Sariska Tiger Reserve, India. Conserv Soc 9(1):54-64

UNEP-WCMC and IUCN (2016). Protected Planet Report 2016. NEP-WCMC and IUCN: Cambridge UK and Gland, Switzerland. https:/wdpa.s3.amazonaws.com/ Protected_Planet_Reports/2445\%20Global\%20Protected\%20Planet\%202016_ WEB.pdf

Vijayan VS (1991) Keoladeo National Park Ecology Study (1980-1990). Bombay Natural History Society, Mumbai, p 337

Weisbrod BA (1964) Collective consumption services of individual consumption goods. Q J Econ 78(3):471-477

Wilkie DS, Morelli GA, Demmer J, Starkey M, Telfer P, Steil M (2006) Parks and people: Assessing the human welfare effects of establishing protected areas for biodiversity conservation. Conserv Biol 20(1):247-249

Wilkie D, Adams WM, Redford KH (2008) Protected areas, ecological scale, and governance: a framing paper, Protected Areas, Governance, and Scale. Wildlife Conservation Society, Working Paper, 36

Zeeshan M, Azeez PA (2016) Hydro-chemical characterization and quality assessment of a Western Himalayan river, Munawar Tawi, flowing through Rajouri district, Jammu and Kashmir, India. Environ Monit Assess 188(9):520

Zeeshan M, Prusty BAK (2014) Environmental scenario along river basins: A case study on Gambhiri river, Rajasthan. India. Paper presented at the Environmental Conference in Central University of Kerala, India, p 29

Zeeshan M, Shrivastava N, Prusty BAK (2013) Public opinion about environmental issues in the catchment of Keoladeo National Park, Rajasthan, Paper presented at the National Conference on Forest and Wildlife (Present Status, Future Needs and Challenges Ahead), Bharatpur, Rajasthan, India., p 35

\section{Submit your manuscript to a SpringerOpen ${ }^{\circ}$ journal and benefit from:}

- Convenient online submission

- Rigorous peer review

- Immediate publication on acceptance

- Open access: articles freely available online

- High visibility within the field

Retaining the copyright to your article 